\title{
Efficacy of Aluminum Hydroxides as Inhibitors of Alkali-Silica Reactions
}

\author{
Alexey Brykov, Anna Anisimova \\ Department of Technology of Constructional and Special Binders, Faculty of Chemistry of Substances and Materials, St. Petersburg \\ State Institute of Technology, St. Petersburg, Russia. \\ Email: brykov@yahoo.com
}

Received October $6^{\text {th }}, 2013$; revised November 21 ${ }^{\text {st }}, 2013$; accepted December $6^{\text {th }}, 2013$

Copyright (C) 2013 Alexey Brykov, Anna Anisimova. This is an open access article distributed under the Creative Commons Attribution License, which permits unrestricted use, distribution, and reproduction in any medium, provided the original work is properly cited.

\begin{abstract}
A comparative study of amorphous and crystalline forms of commercial aluminum hydroxides as inhibitors of alkalisilica reactions in Portland cement mortars has been performed. It was found that at dosages of $1 \%$ to $3 \%$, amorphous aluminum hydroxide can efficiently inhibit alkali-silica expansion of Portland cement compositions. High inhibiting activity of amorphous $\mathrm{Al}(\mathrm{OH})_{3}$ additives may be explained by their ability to actively bind $\mathrm{Ca}(\mathrm{OH})_{2}$ formed by the hydration of silicate phases of cement, to form ettringite (with participation of gypsum). Crystalline $\mathrm{Al}(\mathrm{OH})_{3}$ additives that do not possess the ability to interact with $\mathrm{Ca}(\mathrm{OH})_{2}$ even after additional grinding, however, demonstrate week properties to inhibit alkali-silica expansion. This may indicate that the inhibitory effect of $\mathrm{Al}(\mathrm{OH})_{3}$ at least-partly, may be given by its influence on the concentration of $\mathrm{Al}^{3+}$ ions in the pore solution. Some expansion of the samples with admixtures of $\mathrm{Al}(\mathrm{OH})_{3}$ observed during the alkaline expansion accelerated test procedure is not associated with the formation of ettringite and is only due to alkali-silicate reactions.
\end{abstract}

Keywords: Aluminum Hydroxide; Alkali-Silica Reaction; Inhibition; Portland Cement; Concrete

\section{Introduction}

As it is well known, the use of highly active mineral additives-fly ash, silica fume, metakaolin - is the most effective way to suppress the alkali-silica reactions applied in practice [1-7]. High efficiency of active mineral additives as inhibitors is due to their pozzolanic properties (an ability to bind $\mathrm{Ca}(\mathrm{OH})_{2}$ into C-S-H) and the ability to bind alkaline compounds. Several studies have showed a high inhibitory activity of aluminosilicate additive compared to their siliceous analogs (e.g., metakaolin over silica fume superiority) [7,8]. It is assumed that the incorporation of aluminum into the Si-O chains of C-S-H promotes binding of alkali ions from pore solution [4,9]. According to other point of view, aluminum adsorbs on particles of reactive aggregates to form inactive aluminosilicate complexes, which guarantee an advanced inhibitory effect [10].

At the same time, some of the aluminum compounds are used as alkali-free accelerators for mortars and concretes $[11,12]$. One component of the accelerating admixtures of this type is highly dispersed amorphous modifications of aluminum hydroxides [13]. In the presence of aluminum hydroxides, the decrease in setting time of cement paste is due to rapid formation of ettringite with participation of $\mathrm{Ca}(\mathrm{OH})_{2}$ and gypsum $[13,14]$.

The effect of highly dispersed amorphous aluminum hydroxides on the hydration of Portland cement was studied in [15]. It was established that the small dosages (1\% of the cement weight) of amorphous aluminum hydroxides have no adverse effect on the cement hardening in the early period (1 day), whereas, on the contrary, they cause somewhat increase in the 1 day strength as well as in the following period of the hydration. With dosage of amorphous aluminum hydroxides 3\% - 6\%, 1 day strength is mainly decreased several fold in comparison with the reference sample. The strength of the cement paste in later age decreases too, although differences become lesser with increasing age; in this case, the higher the dose, the greater the loss of the strength by the stone.

An ability of amorphous aluminum hydroxides to bind intensively free $\mathrm{Ca}(\mathrm{OH})_{2}$ allows the idea that these substances could be effective in inhibiting alkali-silica reac- 
tion. This idea is based on the role of calcium in the alkali expansion processes [16]. Alkali silica gel itself, not containing calcium, has high mobility and may be therefore easily and rapidly removed from the formation zone. The presence of calcium, which forms bridging bonds between single silicate ions, makes gel immobile. As a result, the gel accumulates in the formation zones with the appearance of dangerous inner stresses. As known, the increase in the $\mathrm{Ca}(\mathrm{OH})_{2}$ content in the cement compositions containing a reactive filler which facilitates alkali expansion $[17,18]$. Therefore, the ability of active mineral additives to bind $\mathrm{Ca}(\mathrm{OH})_{2}$ is considered by some researchers as one of the main reasons responsible for their inhibition effect [19]. So, it would be interesting to investigate the efficiency of aluminum hydroxides, and further - of other aluminum compounds as inhibitors of alkali silicate reactions and alkali corrosion of Portland cement compositions.

An objective of this work is to carry out a study of amorphous aluminum hydroxides as inhibitors of alkali expansion of Portland cement mortars and concretes. To find out more clearly the action of amorphous $\mathrm{Al}(\mathrm{OH})_{3}$, crystalline forms of $\mathrm{Al}(\mathrm{OH})_{3}$ were also investigated; moreover, different forms of $\mathrm{Al}(\mathrm{OH})_{3}$ were compared in sense of their activity to bind $\mathrm{CaO}$ from saturated $\mathrm{Ca}(\mathrm{OH})_{2}$ solution.

The relevance of this study is due to the prospect of using multi-functional additives that would give an optimal solution to solve several tasks in concrete technology.

\section{Experimental Part}

\subsection{Materials}

As the research subjects, the following types of comercially available aluminum hydroxides were used: amorphous $\mathrm{Al}(\mathrm{OH})_{3}$ Geloxal (Industrias Químicas del Ebro, Spain), amorphous $\mathrm{Al}(\mathrm{OH})_{3}$ SiTau (P \& J Cretechem (P) Ltd, India), the crystalline $\mathrm{Al}(\mathrm{OH})_{3}$ (hydrargillite) GD-18 ("BaselCementPikalyovo", Russia). Properties of aluminum hydroxides are shown in Table 1. Aluminum hydroxide GD18 additionally grinded in vibro-grinder was also tested in experiments.

Portland cement CEM $142.5 \mathrm{~N}$ was used. Phase composition according to petrographic analysis is, wt\%: alite 52-53, belite 18-20, intermediate phase 20-22, gypsum $\left(\mathrm{CaSO}_{4} \cdot 2 \mathrm{H}_{2} \mathrm{O}\right) 3-4$, anhydrite $1, \mathrm{CaCO}_{3} 2$.

As aggregate, a quartz-feldspar sand of the following fractional composition, wt\%, was used: $1.25-2.5 \mathrm{~mm}-$ 5.27, $0.63-1.25 \mathrm{~mm}-27.5 ; 0.315-0.63 \mathrm{~mm}-27.5$; $0.16-0.315 \mathrm{~mm}-17.5$. In the initial aggregate, the content of $\mathrm{SiO}_{2}$ dissolvable in $\mathrm{NaOH}$ and determined by the method described in GOST 8269.0-97 specification is equal to 0 , and aggregate is not reactive to alkali environment. Therefore, sand was previously ignited for $4 \mathrm{hrs}$ at $1080^{\circ} \mathrm{C}$ followed by a rapid cooling to ambient temperature. After this procedure, soluble $\mathrm{SiO}_{2}$ content has reached $80 \mathrm{mmol} / \mathrm{l}$.

\subsection{Testing Methods}

Pozzolanic activity of aluminum hydroxides was determined by absorption of $\mathrm{CaO}$ from saturated solution of $\mathrm{Ca}(\mathrm{OH})_{2}[20]$.

The alkali-silica expansion of cement-sand mortars with the addition of aluminum hydroxides and control samples (without additives) was investigated by the accelerated test in accordance with GOST 8269.0 specification (analog to mortar-bar test method ASTM C 1260).

A reference mortar mix were prepared by mixing sand with cement at a ratio of 2.25:1 (by weight), water-tosolid ratio was 0.125 . Mixtures with $\mathrm{Al}(\mathrm{OH})_{3}$ additives in amount of 1 and $3 \mathrm{wt} \%$ of cement weight were similarly prepared. Dry blends were mixed with water at the same water-to-solid ratio of 0.125 . In case of amorphous $\mathrm{Al}(\mathrm{OH})_{3}$, a plasticizing agent, Melflux 2651, was used ( $0.05 \%$ by the cement weight).

Mortar mixes were put into molds $(20 \times 20 \times 100) \mathrm{mm}$. In accordance with the procedure after 1 day storage at $100 \% \mathrm{RH}$ and $20^{\circ} \mathrm{C}$, samples were demolded and put in water at $80^{\circ} \mathrm{C}$ for one day. Samples were then cooled in a sealed box to $20^{\circ} \mathrm{C}$ and samples' lengths were measured. During the test period, samples were being stored in $1 \mathrm{M}$ $\mathrm{NaOH}$ at $80^{\circ} \mathrm{C}$, daily measurements of samples were performed (total test duration was 2 weeks).

\section{Results and Discussion}

Results of investigation of the binding of $\mathrm{CaO}$ from saturated $\mathrm{Ca}(\mathrm{OH})_{2}$ solution are shown in Figure 1.

Figure 1 shows that the highest absorption of $\mathrm{CaO}$ is

Table 1. Characteristics of aluminum hydroxides.

\begin{tabular}{ccc}
\hline Modification of $\mathrm{Al}(\mathrm{OH})_{3}$ & Specific surface area, $\mathrm{m}^{2} / \mathrm{g}$ & Loss on ignition at $900^{\circ} \mathrm{C}$, wt $\%$ \\
\hline Amorphous "Geloxal” & 17.8 & 47.3 \\
Amorphous "SiTau” & 25.0 & 48.3 \\
Crystalline "GD-18” & 0.095 & 34.6 \\
Crystalline "GD-18" (after grinding) & 0.362 & 34.6 \\
\hline
\end{tabular}




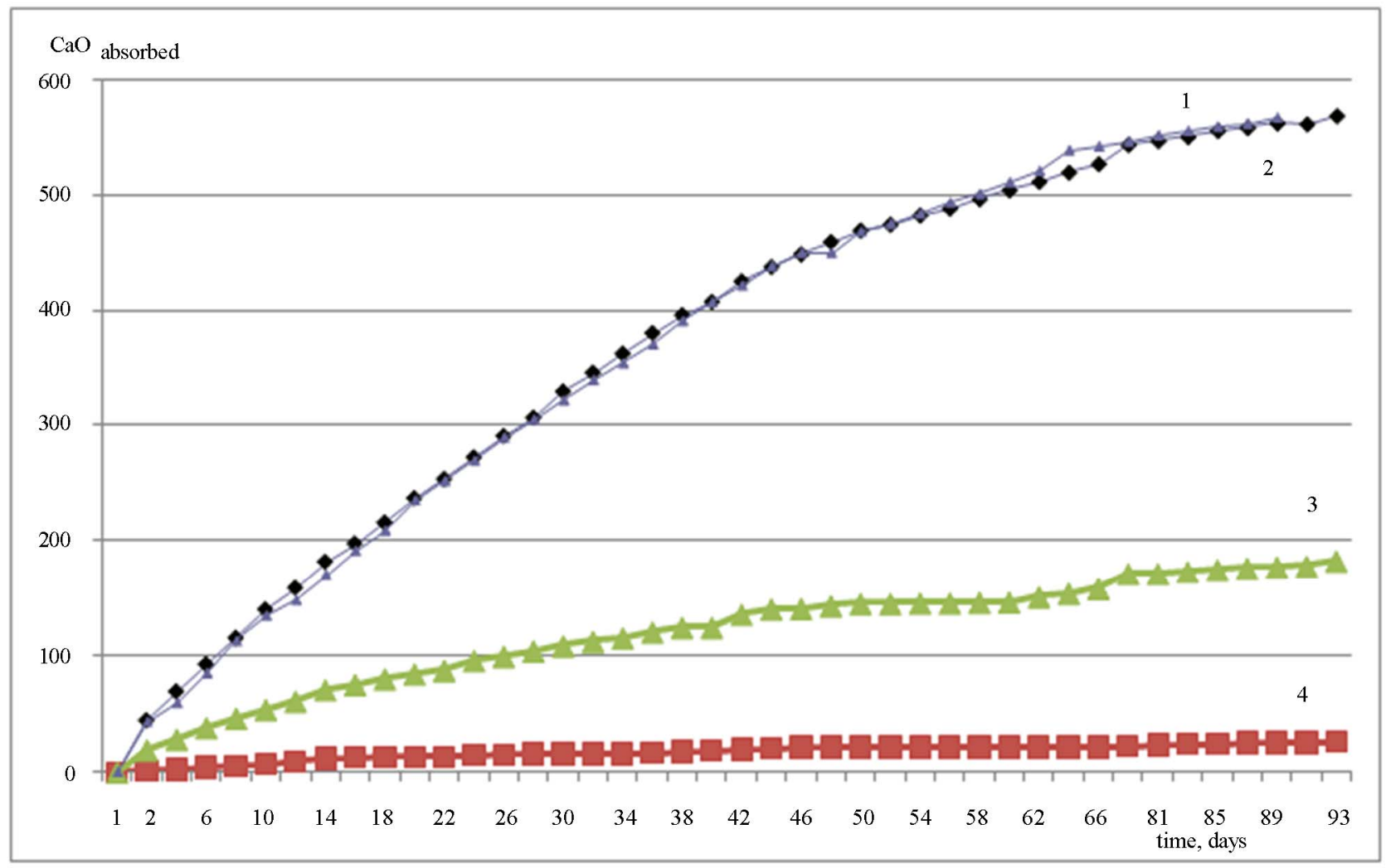

Figure 1. The absorption of $\mathrm{CaO}$ (mg/g) by aluminum hydroxides versus time (days): 1—SiTau, 2-Geloxal, 3-GD18 (additionally grinded), 4-GD18.

exhibited by amorphous $\mathrm{Al}(\mathrm{OH})_{3}$ Geloxal and SiTau, which by the age of 3 months, almost reach the limit on the binding capacity by $\mathrm{Ca}(\mathrm{OH})_{2}$, corresponding to 600 $\mathrm{mg} \mathrm{CaO}$ per $1 \mathrm{~g}$ of $\mathrm{Al}(\mathrm{OH})_{3}$. The $\mathrm{CaO}$ absorption curves virtually coincide for these two types of amorphous $\mathrm{Al}(\mathrm{OH})_{3}$; this is obviously due to their similar characteristics: specific surface area, the content of $\mathrm{Al}_{2} \mathrm{O}_{3}$, and degree of amorphization.

In cement paste or mortar mixture, $\mathrm{Al}(\mathrm{OH})_{3}$ interacts actively with $\mathrm{Ca}(\mathrm{OH})_{2}$ and gypsum with formation of ettringite:

$$
\begin{aligned}
& 2 \mathrm{Al}(\mathrm{OH})_{3}+3 \mathrm{Ca}(\mathrm{OH})_{2}+3\left(\mathrm{CaSO}_{4} \cdot 2 \mathrm{H}_{2} \mathrm{O}\right)+2 \mathrm{H}_{2} \mathrm{O} \\
& \rightarrow 3 \mathrm{CaO} \cdot \mathrm{Al}_{2} \mathrm{O}_{3} \cdot 3 \mathrm{CaSO}_{4} \cdot 32 \mathrm{H}_{2} \mathrm{O}
\end{aligned}
$$

As is seen in Figure 1, the crystalline $\mathrm{Al}(\mathrm{OH})_{3}$ binds almost no $\mathrm{Ca}(\mathrm{OH})_{2}$, but additional grinding, whereby the specific surface area is increased by 4 times, provides binding $\mathrm{CaO}$ capacity of $200 \mathrm{mg}$ per $1 \mathrm{~g}$ of $\mathrm{Al}(\mathrm{OH})_{3}$ by three months.

Figures 2-5 show the dependence of the expansion of mortar samples stored in the conditions of an accelerated test procedure on time. From these figures it follows that to end of the test (14 days), an expansion of control mortar sample is about $0.3 \%$, i.e., about 3 times higher than the threshold value $(0.1 \%)$, which is a criterion for char- acterizing the aggregate as a reactive or non-reactive to alkalis.

The influence of different kinds of amorphous $\mathrm{Al}(\mathrm{OH})_{3}$ on the dynamics of the expansion (Figures 2 and $\mathbf{3}$ ) is almost equal: in both cases the dosage of $3 \%$ is sufficient to prevent exceeding expansion of the samples below the maximum value of $0.1 \%$. However, as it can be seen from Figures 2 and 3, additives of amorphous $\mathrm{Al}(\mathrm{OH})_{3}$ are also very effective at lower doses (1\%) — curves for different dosages are almost the same (Figure 3), or differs very bit from each other (Figure 2). Thus, at doses of $1 \%-3 \%$ amorphous aluminum hydroxide can be an effective inhibitor of alkali expansion.

Admixtures of crystalline $\mathrm{Al}(\mathrm{OH})_{3}$ are less effective. The increasing of the dosage or additional grinding does not affect the efficiency of $\mathrm{Al}(\mathrm{OH})_{3}$ as alkali-silica reaction inhibitors (Figures $\mathbf{4}$ and 5). The expansion goes over the critical limit of $0.1 \%$, which is referred as a criterion of safety for aggregate during the alkali expansion test.

It is known that $\mathrm{Ca}(\mathrm{OH})_{2}$ formed by the hydration of silicate phases of cement involves in destructive alkali silicate reactions and contributes to the destructive process of concrete expansion [7]. The high inhibiting properties of amorphous $\mathrm{Al}(\mathrm{OH})_{3}$ may be due to the high ability to bind $\mathrm{Ca}(\mathrm{OH})_{2}$ (Figure 1). Therefore, in case of siliceous additives usage, gel C-S-H is formed, but in the 


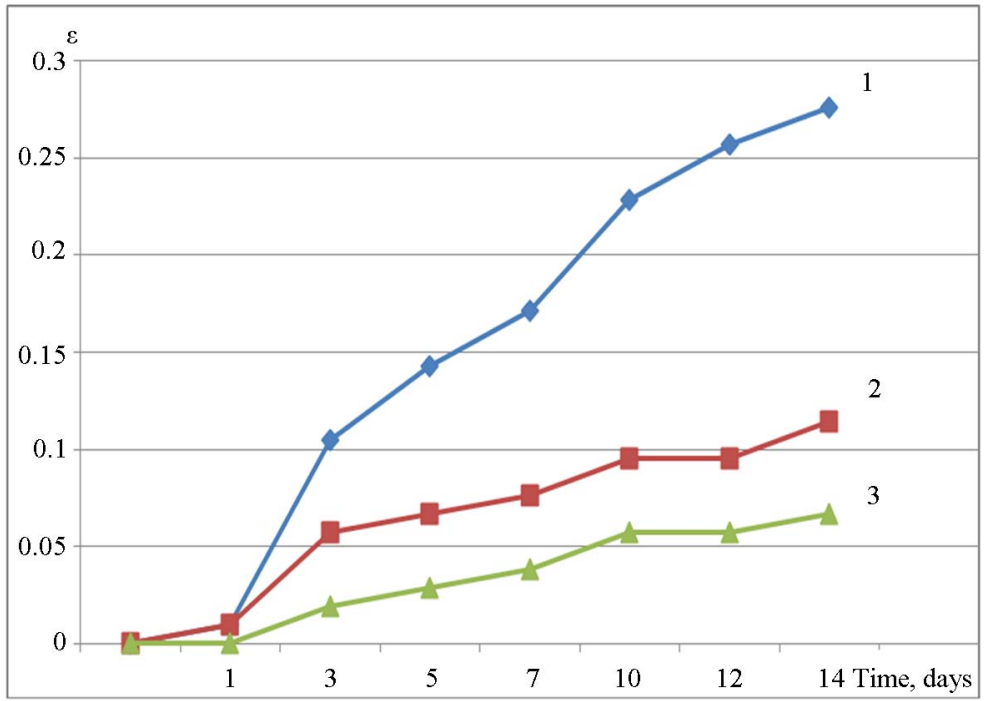

Figure 2. Expansion $\varepsilon(\%)$ of samples with the addition of $\mathrm{Al}(\mathrm{OH})_{3}$ “SiTau” stored in $1 \mathrm{M} \mathrm{NaOH}$ versus time (days): $1-0 \%$ of $\mathrm{Al}(\mathrm{OH})_{3}$ (by weight of cement), $2-1 \%, 3-3 \%$.

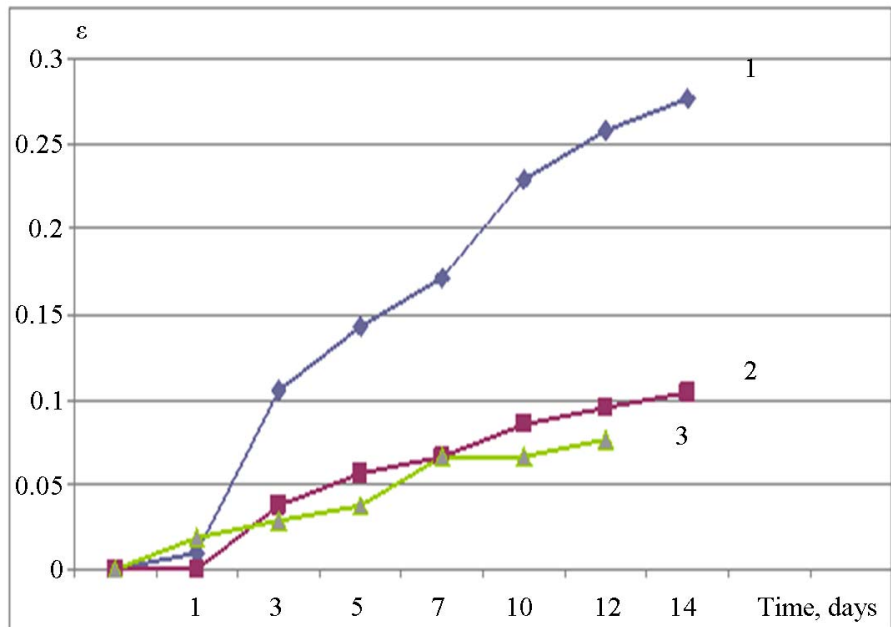

Figure 3. Expansion $\varepsilon(\%)$ of samples with the addition of $\mathrm{Al}(\mathrm{OH})_{3}$ “Geloxal” stored in $1 \mathrm{M} \mathrm{NaOH}$ versus time (days): $1-0 \%$ of $\mathrm{Al}(\mathrm{OH})_{3}$ (by weight of cement), $2-1 \%, 3-3 \%$.

case of $\mathrm{Al}(\mathrm{OH})_{3}$ the resultant is ettringite.

On the other hand, the crystalline $\mathrm{Al}(\mathrm{OH})_{3}$, which possesses almost no pozzolanic activity (the absence of the ability to bind $\mathrm{Ca}(\mathrm{OH})_{2}$ ), also shows some inhibitory effect (Figure 4). It should be noted that additional grinding for the purpose of increasing surface area and pozzolanic activity does not improve the inhibitory properties. This may indicate that the inhibitory effect of $\mathrm{Al}(\mathrm{OH})_{3}$ at least-partly, may be given by its influence on the concentration of $\mathrm{Al}^{3+}$ ions in the pore solution. As noted above, increasing the concentration of $\mathrm{Al}^{3+}$ ions in the presence of $\mathrm{Al}(\mathrm{OH})_{3}$ leads to intense adsorption of $\mathrm{Al}^{3+}$ ions on the surface of reactive aggregate particles and formation of poorly soluble aluminosilicate complexes passivating reactive aggregates.

As soon as $\mathrm{Al}(\mathrm{OH})_{3}$ additives, primarily those amor- phous, are actively involved in ettringite formation, this may be accompanied by expansion of mortar samples at the early stages. Meanwhile, the initial measurement of the samples length takes place two days after mixing, so by that moment gypsum is almost fully consumed and the formation of ettringite is basically completed.

Nevertheless, to ensure that the expansion of samples is due to alkali-silica reaction, but not a formation of ettringite, an additional series of samples were stored in distilled water (instead of $\mathrm{NaOH}$ solution), with all other conditions left unchanged. Test results showed that under these conditions neither reference sample nor samples with crystalline $\mathrm{Al}(\mathrm{OH})_{3}$ at different dosages do not undergo any expansion. Samples with amorphous $\mathrm{Al}(\mathrm{OH})_{3}$ and GD18 (additionally grinded) after two weeks of exposure show some small extension (approximately 


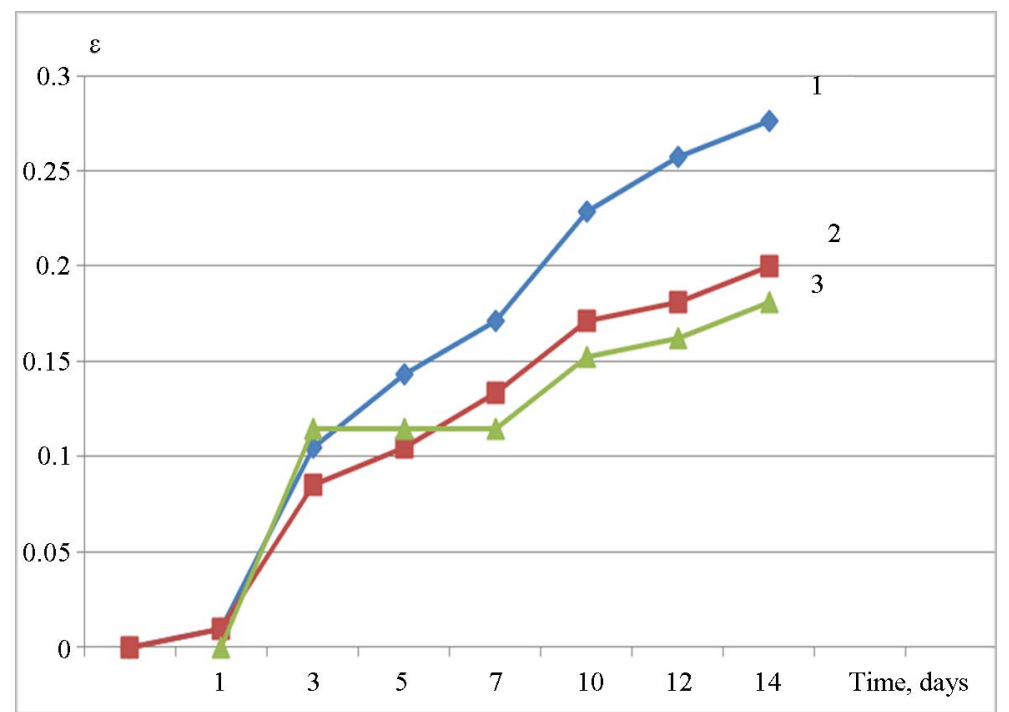

Figure 4. Expansion $\varepsilon(\%)$ of samples with the addition of $\mathrm{Al}(\mathrm{OH})_{3}$ “GD18” stored in $1 \mathrm{M}$ NaOH versus time (days): $1-0 \%$ of $\mathrm{Al}(\mathrm{OH})_{3}$ (by weight of cement), $2-1 \%, 3-3 \%$.

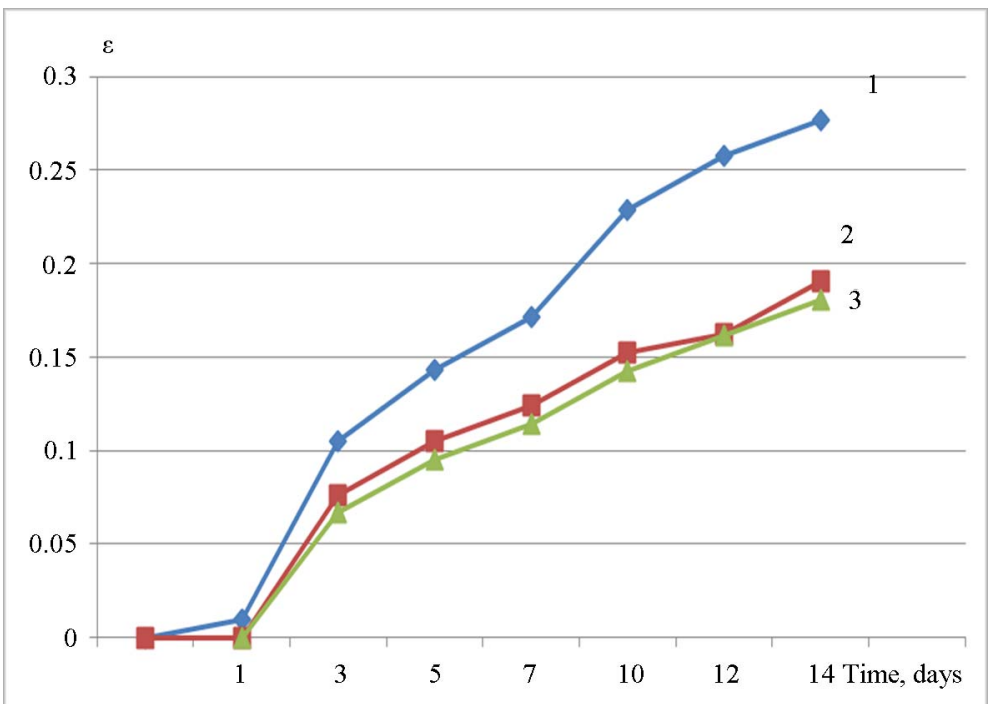

Figure 5. Expansion $\varepsilon(\%)$ of samples with $\mathrm{Al}(\mathrm{OH})_{3}$ “GD18” (after additional grinding) stored in $1 \mathrm{M} \mathrm{NaOH}$ versus time (days): $1-0 \%$ of $\mathrm{Al}(\mathrm{OH})_{3}$ (by weight of cement), $2-1 \%, 3-3 \%$.

$\sim 0.01 \%$ ), which can be neglected.

\section{Conclusions}

1) At dosages of $1 \%$ - 3\% amorphous aluminum hydroxide can be effective in inhibiting alkali expansion of Portland cement mortars and concretes. Crystalline $\mathrm{Al}(\mathrm{OH})_{3}$ additives are less effective. Dosage increasing or additional grinding does not affect the inhibitory efficiency of the crystalline $\mathrm{Al}(\mathrm{OH})_{3}$.

2) High inhibiting activity of amorphous $\mathrm{Al}(\mathrm{OH})_{3}$ additives may be explained by their ability to actively bind $\mathrm{Ca}(\mathrm{OH})_{2}$ formed by the hydration of silicate phases of cement, to form ettringite. Inhibitory effect of $\mathrm{Al}(\mathrm{OH})_{3}$ can also be due to its influence on the $\mathrm{Al}^{3+}$ ions concentration in the pore solution.

An expansion of the samples observed with admixtures of $\mathrm{Al}(\mathrm{OH})_{3}$ during the alkaline expansion accelerated test procedure is not associated with the formation of ettringite and is only due to alkali-silicate reactions.

\section{REFERENCES}

[1] S. Chandra and L. Berntsson, "Use of Silica Fume in Concrete,” In: S. Chandra, Ed., Waste Materials Used in Concrete Manufacturing, Noyes Publications, Westwood, 1997.

[2] B. Lothenbach, K. Scrivener and R. Hooton, "Supple- 
mentary Cementitious Materials," Cement and Concrete Research, Vol. 41, No. 12, 2011, pp. 1244-1256. http://dx.doi.org/10.1016/j.cemconres.2010.12.001

[3] M. D. A. Thomas and K. J. Folliard, "Concrete Aggregates and the Durability of Cocncrete,” In: C. Page and M. Page, Eds., Durability of Concrete and Cement Composites, CRC Press, New York, 2007.

[4] T. Ramlochan, M. Thomas and K. Gruber, "The Effect of Metakaolin on Alkali-Silica Reaction in Concrete," Cement and Concrete Research, Vol. 30, No. 3, 2000, pp. 339-344. http://dx.doi.org/10.1016/S0008-8846(99)00261-6

[5] M. H. Shehata and M. Thomas, "Use of Ternary Blends Containing Silica Fume and Fly Ash to Suppress Expansion Due to Alkali-Silica Reaction in Concrete," Cement and Concrete Research, Vol. 32, No. 3, 2002, pp. 341349. http://dx.doi.org/10.1016/S0008-8846(01)00680-9

[6] R. Siddique and M. I. Khan, "Supplementary Cementing Materials,” Springer, Berlin, 2011.

http://dx.doi.org/10.1007/978-3-642-17866-5

[7] M. Thomas, "The Effect of Supplementary Cementing Materials on Alkali-Silica Reaction: A Review," Cement and Concrete Research, Vol. 41, No. 12, 2011, pp. 12241231. http://dx.doi.org/10.1016/j.cemconres.2010.11.003

[8] T. Chappex and K. Scrivener, "Alkali Fixation of C-S-H in Blended Cement Pastes and Its Relation to Alkali Silica Reaction," Cement ANd Concrete Research, Vol. 42, No. 8, 2012, pp. 1049-1054. http://dx.doi.org/10.1016/j.cemconres.2012.03.010

[9] S.-Y. Hong and F. Glasser, "Alkali Sorption by C-S-H and C-A-S-H Gels: Part II. Role of Alumina,” Cement and Concrete Research, Vol. 32, No. 8, 2002, pp. 11011111. http://dx.doi.org/10.1016/S0008-8846(02)00753-6

[10] T. Chappex and K. L. Scrivener, "The Influence of Aluminium on the Dissolution of Amorphous Silica and Its Relation to Alkali Silica Reaction," Cement and Concrete Research, Vol. 42, No. 12, 2012, pp. 1645-1649. http://dx.doi.org/10.1016/j.cemconres.2012.09.009

[11] R. Myrdal, “Accelerating Admixtures for Concrete,”
State of the Art: SINTEF Report N SBF BK A07025, Trondheim, 2007.

[12] R. Rixom and N. Mailvaganam, "Chemical Admixtures for Concrete,” E\&FN Spon, London, 1999. http://dx.doi.org/10.4324/9780203017241

[13] Q. Xu and J. Stark, “The Chemical Action of $\mathrm{Al}(\mathrm{OH})_{3}$ Accelerators in the Early Hydration of Portland Cements,” ZementKalkGips, Vol. 61, No. 3, 2008, pp.82-92.

[14] A. Brykov and A. Vasil'ev, "Accelerators of Setting and Hardening for Shotcrete," Cement and Its Applications, No. 3, 2012, pp. 112-117.

[15] A. Brykov, A. Vasil'ev and M. Mokev, "Hydration of Portland Cement in the Presence of High Activity Aluminum Hydroxides,” Russian Journal of Applied Chemistry, Vol. 85, No. 12, 2012, pp. 1793-1799. http://dx.doi.org/10.1134/S1070427212120014

[16] T. Ichikawa and M. Miura, "Modified Model of AlkaliSilica Reaction," Cement and Concrete Research, Vol. 37, No. 9, 2007, pp. 1291-1297. http://dx.doi.org/10.1016/j.cemconres.2007.06.008

[17] R. F. Bleszynski, "Microstructural Studies of Alkali-Silica Reaction in Fly Ash Concrete Immersed in Alkaline Solutions," Advanced Cement Based Materials, Vol. 7, No. 2, 1998, pp. 66-78. http://dx.doi.org/10.1016/S1065-7355(97)00030-8

[18] H. Wang and J. Gillot, "Mechanism of Alkali-Silica Reaction and the Significance of Calcium Hydroxide," Cement and Concrete Research, Vol. 21, No. 4, 1991, pp. 647-654.

http://dx.doi.org/10.1016/0008-8846(91)90115-X

[19] S. Chatterji and N. Thaulow, "Some Fundamental Aspects of Alkali-Silica Reaction," Proceedings of the 11th International Conference on Alkali-Aggregate Reaction, Quebec City, June 2000, pp. 21-29.

[20] Y. M. Butt and V. V. Timashev, "The Practical Cause on the Chemical Technology of Mineral Binders,” Vishayashkola, Moskva, 1973. 